\title{
A Theory of Sequential-Stage Signaling: Evidence from Equity-Crowdfunding
}

\author{
Kourosh Shafi*1 and Massimo Colombo ${ }^{\dagger 2}$ \\ ${ }^{1}$ California State University, East Bay \\ ${ }^{2}$ Politecnico di Milano
}

October 9, 2020

\begin{abstract}
We develop a theory of sequential-stage signaling that addresses how issuers' signals are perceived by the receivers when there is an intermediary that facilitates the transaction and the intermediary's incentives may not be aligned with those of signal receivers. We propose that boundedly-rational receivers may misinterpret costly signals indicating issuers' underlying quality and consider signals revealing intermediary's private information on issuers' quality to be more informative. We apply the theory to the context of equity crowdfunding offerings in the U.S. While the signal from venture backing by professional investors is associated with more positive outcomes of crowdfunding campaigns, our findings show that this effect is partially mediated by the equity stake requested by crowdfunding platforms as compensation for their services. The platforms' "skin in the game" sends an additional easily-interpretable signal to crowd investors on venture quality.
\end{abstract}

Keywords: Signaling Theory, Equity Crowdfunding, Skin in the Game

JEL Classification: D26, G24, L26, M13

\footnotetext{
*kourosh.shafi@csueastbay.edu

† massimo.colombo@polimi.it
} 


\section{Introduction}

Since Spence's (1973) seminal paper, signaling theory has become a fundamental paradigm to examine transactions between two exchange parties (e.g., job candidates and employers, entrepreneurs prospecting investors) when information asymmetries between them impede the transaction. A signal is an investment that is more costly to replicate for lower quality issuers than for higher quality ones. If sending a signal is profitable only for high-quality exchange parties, the signal creates a separating equilibrium making high-quality parties distinguishable from their low-quality counterparts (for reviews, see Connelly, Certo, Ireland, and Reutzel (2011); Bergh, Connelly, Ketchen Jr, and Shannon (2014)). More recently, the theory has been expanded to consider multiple signals that may complement or replace each other (Pollock, Chen, Jackson, and Hambrick, 2010; Khoury, Junkunc, and Deeds, 2013; Steigenberger and Wilhelm, 2018; Colombo, Meoli, and Vismara, 2019; Vanacker, Forbes, Knockaert, and Manigart, 2020), or how the attributes of receivers may influence signal effectiveness (Vanacker and Forbes, 2016). In particular, Drover, Wood, and Corbett (2018) have argued that signal receivers being boundedly rational, may experience difficulties in interpreting and fully considering multiple signals in their decisions. An issue that has gone unnoticed in the signaling literature is that intermediaries may play a key role in addressing the cognitive limitations of signal receivers.

In many markets, intermediaries can help address inefficiencies that arise due to information asymmetries between buyers and sellers, thus facilitating transactions. Intermediaries receive and interpret the signals sent by sellers before buyers, the ultimate receivers of these signals buyers decide after observing the intermediaries' actions. The actions of the intermediaries may then represent an additional signal indicating the quality of sellers, that is easier for boundedlyrational buyers to interpret than the signals originally sent by sellers. For example, this may happen because buyers have confidence in the intermediaries' expertise in judging seller quality. However, it is questionable whether and when buyers can safely rely on the signals sent by intermediaries, as intermediaries may have interests that are misaligned with those of buyers. For example, intermediaries may show myopic behavior and seek to earn commission fees by facilitating more transactions, without considering quality of sellers. In this case, the actions undertaken by intermediaries might not be informative to buyers and would not help them disentangle highquality sellers from low-quality ones. This study develops a theory for sequential-stage signals 
and applies it to the emerging context of equity crowdfunding.

Equity crowdfunding offers new ventures the opportunity to sell equity shares to a crowd of investors through the intermediation of a crowdfunding platform, and provides an ideal setting for this study. In 2016 the Securities Exchange Commission in the U.S. adopted Regulation Crowdfunding (mandated under Title III of the Jumpstart Our Business Startups [JOBS] Act) that was designed to provide smaller businesses and startups (hereafter, ventures) with an innovative method of raising capital while still assuring investor protection. A crowdfunding issuer must conduct its offering exclusively through an online platform operated by an intermediary that is registered either as a broker-dealer or as a "funding portal," a new type of entity created by the Regulation Crowdfunding rule-making. ${ }^{1}$ Regulation Crowdfunding additionally requires that intermediaries provide disclosures to investors about the compensation they receive, and allows them to take a financial interest in crowdfunding issuers only as a compensation for their services. $^{2}$

Crowd investors typically lack the financial sophistication and investment experience possessed by professional investors. Moreover, they generally invest small amounts, which do not warrant extensive expenditure of time and effort for due diligence and collection of additional information on ventures (Ahlers, Cumming, Günther, and Schweizer, 2015; Shafi, 2019). Thus, while it is true that prior equity funding by professional investors, especially highly reputable ones, clearly is a quality signal on which ventures can rely to obtain additional financing (Stuart, Hoang, and Hybels, 1999), this statement appears to rest on a strong assumption about the cognitive abilities of crowd investors and the extent to which they correctly interpret this signal. Furthermore, crowdfunding platforms have the incentives and abilities to easily interpret the quality signal sent by crowdfunding issuers (ventures) that are backed by professional investors. Accordingly, they can convey their private information to crowd investors by taking equity stakes in these ventures as part of their compensation for arranging the offerings. The "skin in the game" showcased by platforms sends to crowd investors an additional signal about

\footnotetext{
${ }^{1}$ https://www.sec.gov/divisions/marketreg/tmcompliance/cfintermediaryguide.htm and https: //www.finra.org/about/funding-portals-we-regulate

${ }^{2}$ More specifically, Regulation Crowdfunding prohibits intermediaries from "having a financial interest in an issuer that is offering or selling securities on its platform unless the intermediary receives the financial interest as compensation for the services provided to or for the benefit of the issuer in connection with the offer or sale of securities in a crowdfunding offering and the financial interest consists of securities of the same class and having the same terms, conditions and rights as the securities being offered or sold in the crowdfunding offering through the intermediary's platform. See https://www.sec.gov/divisions/marketreg/tmcompliance/cfintermediar yguide.htm
} 
the underlying quality of the venture, which crowds can easily interpret. At the same time, it alleviates crowd investors' concerns about platforms' opportunistic behavior tied to promoting low-quality offerings just to earn commission fees, which is detrimental for crowd investors' long-term returns. Therefore, we hypothesize that platforms' "skin in the game" mediates the positive relationship between the signal associated with a focal venture's prior equity funding by professional investors and crowdfunding outcomes. We test our hypotheses using data on ventures raising funding under Regulation Crowdfunding in the U.S. and find evidence consistent with our hypotheses.

Our paper offers two main contributions. First, we contribute to the literature interested in the role of signals in strategic entrepreneurship (Bergh et al., 2014), in particular, for mobilizing financial resources (Shafi, Mohammadi, and Johan, 2019). We extend the theory to transactions involving intermediaries whose interests might not be fully aligned with those of the exchange parties. Our sequential-stage signaling theory underlines an intermediaries' capacity to mediate credibly the issuers' signals. Additionally, we highlight the role of incentives (i.e., skin in the game) in transferring risks to investors. Informed intermediaries take enough of a financial interest in issuers to reassure investors that the classic problems of adverse selection and moral hazard are alleviated (Holmstrom and Tirole, 1997; Gorton, Pennacchi, et al., 1995). Second, we contribute to the literature interested in the success of crowdfunding campaigns (Colombo, Franzoni, and Rossi-Lamastra, 2015; Block, Colombo, Cumming, and Vismara, 2018) and the governance of crowdfunding (Cumming, Vanacker, and Zahra, 2019b). Previous studies have studied the role of campaign characteristics and management teams for the success (Shafi, 2019), yet scholars including Dushnitsky and Zunino (2019) and Hornuf and Schwienbacher (2018) have highlighted a research gap on how heterogeneity among equity crowdfunding platforms relates to campaigns' success. Our contribution features one specific governance choice of platforms related to compensation design. In doing so, our research answers the call made by Cumming et al. (2019b) for "more research on how governance mechanisms may limit informational asymmetry and related adverse selection and moral hazard issues in equity crowdfunding." 


\section{Conceptual Background}

\subsection{Signaling in Equity Crowdfunding}

Ahlers et al. (2015) define equity crowdfunding as "a method of financing, whereby an entrepreneur sells a specified amount of equity or bond-like shares in a company to a group of (small) investors through an open call for funding on Internet-based platforms" (p. 958). While the market for equity crowdfunding is nascent, in some countries with favorable regulations such as the UK, the share of equity crowdfunding among all early-stage equity funding is rapidly growing (Zhang, Ziegler, Mammadova, Johanson, Gray, and Yerolemou, 2018). Equity crowdfunding volumes contributed $12.9 \%$ of all UK total seed and venture-stage equity investment in 2017 and grew by $22 \%$ from $£ 272$ million in 2016 to $£ 333$ million in $2017 .{ }^{3}$ Equity crowdfunding seems to provide a viable, alternative source of financing for ventures despite the difficulties crowd investors face to assess the investment opportunities posted on equity crowdfunding platforms.

Indeed, investing in equity crowdfunding presents adverse selection and moral hazard problems for investors (Hertzel and Smith, 1993; Stiglitz, 1985). Adverse selection stems from information asymmetries between prospective investors and entrepreneurs about venture quality. Compared with prospective investors, entrepreneurs have naturally more information about their ventures, which generally are in an early stage, have limited or no track record, and even have sometimes untested products. Thus, entrepreneurs must find ways to credibly communicate their private information to prospective investors. This difficulty is further compounded by the fact that entrepreneurs may be too optimistic or overconfident, and may exaggerate the market potential of their target opportunity or withhold negative information about execution hurdles (Cooper, Woo, and Dunkelberg, 1988; Busenitz and Barney, 1997). Prospective investors also face moral hazard problems, which arise from information asymmetry about entrepreneurs' unobserved actions. Entrepreneurs might divert funds for their private benefits instead of serving their fiduciary responsibilities, engage in excessive risk-taking, or simply shirk from effort expenditure.

Adverse selection and moral hazard in venture investing appear to be more severe problems for crowd investors compared with professional investors (Ahlers et al., 2015). Crowd investors

\footnotetext{
${ }^{3}$ https://www.jbs.cam.ac.uk/fileadmin/user_upload/research/centres/alternative-finance/downl oads/2018-5th-uk-alternative-finance-industry-report.pdf
} 
are at a disadvantage when evaluating investment opportunities in early stage ventures, as they generally do not have the financial expertise relevant to venture investing. Nor they can rely on their "gut feel" based on their experience of previous successful investments, as professional investors often do when facing unknowable risks (Huang and Pearce, 2015). Moreover, crowd investors tend to invest relatively small amounts of money, and expending great amounts of resources and time in due diligence or in the expensive advice of consultants often is often not justifiable considering the expected returns from selecting better investment opportunities. Lastly, it is doubtful that crowd investors can allocate resources and have the abilities to monitor entrepreneurs after investment (e.g., by taking board seats) so as to curb the opportunistic behaviors exhibited by some entrepreneurs. Overall, we expect crowd investors to be exposed to greater risks from information asymmetries than professional investors, and thus to benefit more from signals of venture quality (Bergh et al., 2014), if they require little cognitive effort in interpreting them (Shafi, 2019).

Research on equity crowdfunding has explored the host of signals employed by ventures that make them more successful in fundraising. These signals include the number and human capital of board members (Ahlers et al., 2015), entrepreneurs' business education and their experience (Piva and Rossi-Lamastra, 2018), retained equity by entrepreneurs (Vismara, 2016a), and receipt of prior external funding (Lukkarinen, Teich, Wallenius, and Wallenius, 2016; Kleinert, Volkmann, and Grünhagen, 2018; Ralcheva and Roosenboom, 2018). We extend this line of inquiry by focusing on the intermediary role of crowdfunding platforms, and argue that their actions can reinforce crowd investors' perception of ventures' signals.

\subsection{Skin in the Game}

The existing literature provides a few justifications for issuers (sellers) or intermediaries to retain "skin in the game," which refers to retaining a financial stake in the issued asset (to be sold to prospective investors). Skin in the game is an effective mechanism for mitigating both adverse selection and moral hazard problems. Below we explicate each rationale.

When the issuer has private information on the asset's quality, skin in the game alleviates the adverse selection risks for prospective investors (Brealey, Leland, and Pyle, 1977; DeMarzo and Duffie, 1999; DeMarzo, 2005; Hartman-Glaser, 2017). Skin in the game serves as a signal 
of quality as it is more costly for lower quality sellers to retain a stake in the asset. Consider a portfolio composed of assets of varying quality (either high or low), and assume that only the seller knows the underlying quality of these assets. The sellers of high-quality assets can keep a large enough stake in these assets such that the sellers of low-quality assets cannot find compatible incentives to mimic this behavior. Under this condition, there is a separating equilibrium, and investors can rely on the extent of risk retained by the sellers to infer the sellers' private information about the unobserved quality of the assets on sale.

Retaining a financial stake in an asset can also mitigate moral hazard problems, and align sellers' incentives with those of the prospective investors. Holding skin in the game provides economic incentives for the seller to exert effort and diligently screen the asset before the transaction (Chemla and Hennessy, 2014; Rajan, Seru, and Vig, 2010), thus increasing the probability of originating a high-quality asset. Demiroglu and James (2012) examine the performance of mortgage loans after adopting the Dodd-Frank Wall Street Reform and Consumer Protection Act legislation, which mandates sponsors of new securitization issues to retain at least $5 \%$ of the credit risk of those securities in the transaction. They find that the positive association between ex post loan performance and retaining skin in the game is mostly confined to loans with low documentation where screening is arguably more important to assess borrowers' creditworthiness. ${ }^{4}$ Additionally, after the asset sale, investors' payoff increases with skin in the game since sellers have incentives to expend costly effort in monitoring activities (Pennacchi, 1988; Gorton et al., 1995). Consistent with these arguments, extant evidence suggests that the performance of mortgages originated prior to the credit crisis were lower for mortgages that were securitized than the mortgages that were retained in the originator's portfolio (Mian and Sufi, 2009; Keys, Mukherjee, Seru, and Vig, 2010; Purnanandam, 2011).

\section{Theory and Hypotheses}

\subsection{A Sequential-Stage Signaling Model}

To develop a sequential-stage signaling model, consider a setup that involves three parties to an asset exchange: an issuer, an investor, and an intermediary who interact in two sequential stages.

\footnotetext{
${ }^{4}$ See also Agarwal, Amromin, Ben-David, Chomsisengphet, and Evanoff (2010) for additional evidence on the moral-hazard reducing effects of this legislation on loans' risk premiums and default rates in the U.S.
} 
Let's state our assumptions about these parties before explaining the exchange of information and actions in each stage. The issuer has private information about the underlying quality of the asset it is offering to the investor, which creates a standard adverse selection problem. The issuer can also commit effort after the transaction to improve the quality of the underlying asset. The extent of this effort is difficult to monitor, which creates a standard moral hazard problem. The investor is boundedly rational à la Simon, in the sense that "the scarce resource is not information: it is processing capacity to attend to information" (Simon, 1947). In other words, the investor is rational but has limited cognitive abilities to process information conveyed by the issuer (Drover et al., 2018) and to monitor issuer's behavior. Conversely, we assume that the intermediary is fully rational and is able to correctly interpret the information conveyed by the issuer and to monitor its behavior after the investment. We further assume that the investor is able to observe and correctly interpret the intermediary's actions. The intermediary receives a positive payoff only if the transaction materializes regardless of the underlying asset quality. Hence, the interests of the investor and those of the intermediary are misaligned when the underlying asset quality is low. As a compensation for facilitating transactions, the intermediary asks the issuer either to pay a one-time fixed fee or to give it a share of the underlying asset. In the latter case, the intermediary has "skin in the game," as its payoff increases with the higher value of the asset exchanged.

In the first stage, the issuer can make a costly investment to signal the quality of the asset. To qualify as a signal, the cost of replicating the investment needs to be high enough for low-quality issuers to make it unprofitable. This condition defines a separating equilibrium (Spence, 1973), allowing (fully rational) outside evaluators to distinguish high-quality assets from low-quality ones. The intermediary evaluates issuer's assets including assessment of signals correlated with the asset's quality, and decides: (i) whether or not to offer its intermediation services to the issuer, and if so; (ii) how to be compensated by the issuer. If the intermediary expects that the investor would not to be inclined to enter the transaction, it will abstain from offering its services to the issuer and the exchange will not occur. Conversely, if the intermediary agrees to facilitate the transaction, it prefers compensation by an equity stake over a fixed intermediation fee only if it believes that the underlying asset is of high quality.

In the second stage, the investor evaluates the underlying asset offered by the issuer and decides whether to buy an equity stake in the asset at the price asked for by the issuer. Because 
of its cognitive limitations, the investor may misinterpret the signal sent by the issuer with positive probability, and consider a high quality asset as being of low quality - for instance, the investor may underestimate the cost of replicating the signal. The higher the probability that the investor misinterprets the signal, the less likely that the signal induces the investor to participate in the transaction. However, the investor observes both the signal initially sent by the issuer and the compensation asked for by the intermediary. The fact that the intermediary will have its skin in the game sends an additional signal about the high quality of the issuer's asset. Additionally, skin in the game assures the investor that moral-hazard problems are alleviated, because the intermediary has incentives to monitor the effort committed by the issuer after the transaction takes place.

Our sequential-stage signaling model predicts that after observing the signal sent by the issuer, the intermediary will ask for an equity stake in the asset as compensation for its services. The investor correctly interprets the intermediary's skin in the game as a signal of the high quality of the asset and invests in the asset, even if it may have difficulty in valuing the signal originally sent by the issuer. Accordingly, we formulate a mediation relationship: The positive effect of the signal sent by the issuer on investor's propensity to buy an equity stake in the asset is mediated by the intermediary's decision to ask for a larger equity stake in the issued asset as compensation for its services - intermediary's decision is based on its private information on the asset's quality.

\subsection{Hypotheses}

\subsubsection{Ventures' previous fundraising from professional investors and platform's skin in the game}

We argue that the compensation crowdfunding platforms will ask for in exchange for their services will include a greater equity component if ventures are backed by professional investors such as venture capitalists and business angels (thereafter, $\mathrm{VCs}$ ) before launching their crowdfunding campaigns. Crowdfunding platforms interpret affiliation with VCs as a signal of ventures' unobserved quality and better prospects. They request a greater equity stake in their compensation fees to benefit from the future upside of these high-quality ventures they are helping raise funds. Note that crowdfunding platforms' compensation for their intermediation services can be in the 
form of a fixed cash fee, that is generally proportionate to the amount of capital the focal venture wants to raise, or an equity stake in the venture, or a mix of the two. Below we expand these arguments.

In the process of choosing which ventures to represent, crowdfunding platforms perform extensive due diligence and carefully assess the quality of the ventures, including signals associated with affiliations with VCs. Platforms will lose commission fees if the selected ventures fail in their crowdfunding campaigns, as their commission fees are tied to the success of the campaigns they market to investors. Thus, platforms not only seek to enlist ventures that pass a minimum quality threshold sufficient to attract crowd investors, but also look for the highest quality ventures. Platforms screen the proposals they receive for signals of underlying venture quality among other evaluation criteria. Obtaining funding from VCs is a prominent signal (Stuart et al., 1999). This is so since VCs are in the business of maximizing their financial returns (via taking their portfolio venture public or through a trade sale) and can do so if they are proficient at picking promising ventures. Given VCs' screening abilities (Kerr, Lerner, and Schoar, 2014; Colombo and Grilli, 2010), it is more costly for ventures with lower prospects to succeed in raising outside funding from VCs. In addition, VCs are hands-on investors who provide coaching (Gorman and Sahlman, 1989; Colombo and Grilli, 2010) and access to networking relations (Hochberg, Ljungqvist, and Lu, 2007). These value-added services increase the success likelihood of ventures backed by VCs (Bertoni, Colombo, and Grilli, 2011; Chemmanur, Krishnan, and Nandy, 2011; Puri and Zarutskie, 2012).

We argue that crowdfunding platforms prefer an equity stake in the crowdfunding business over fixed compensation for VC-backed ventures. They do this to benefit from the upside associated with better performing ventures, which makes the value of their equity compensation increase over time. Platforms relative to crowds have more and better resources to expend for due diligence and correct interpretation of the quality signal associated with VC-backing. Accordingly, platforms will likely opt for more equity compensation as an overall share of their compensation fees for VC-backed ventures as they believe in their potential for appreciation in the post-campaign period. Thus, we propose:

Hypothesis 1. There is a positive relationship between a focal venture's previous fundraising from professional investors and the equity stake requested by the platform as compensation for their intermediation services (i.e., skin in the game). 


\subsubsection{Ventures' previous fundraising from professional investors and the outcomes of crowdfunding campaigns}

As was mentioned earlier, ventures' VC-backing is a prominent signal of their quality. Previous studies in crowdfunding show that crowd investors positively value that the venture has previously obtained funding from VCs (Lukkarinen et al., 2016; Vismara, 2016b; Ralcheva and Roosenboom, 2019; Colombo and Shafi, 2019; Mamonov and Malaga, 2019; Kleinert, Volkmann, and Grünhagen, 2020). Therefore, we refrain from specifying a formal hypothesis on the positive relationship between a focal venture's previous backing by VCs and the outcomes of its equity crowdfunding campaign.

\subsubsection{The mediation effect of platforms' skin in the game}

We argue that the positive effect of VC-backing on the outcomes of ventures' crowdfunding campaigns is mediated by the relative share of ventures' equity to the overall compensation fees requested by platforms for performing their intermediation services.

As we mentioned earlier, crowd investors typically have cognitive limitations, as they do not possess the investment experience and sophisticated screening abilities of VCs (Ahlers et al., 2015). They also generally invest small amounts of money, which limits their incentives to devote time and resources to collect information on listed ventures (e.g., by resorting to expensive advice of consultants). Accordingly, previous studies show that crowd investors mainly rely on the easy-to-pick information relating to the campaigns they find on the crowdfunding platforms to make their investment decisions. For example, while analyzing projects posted on Crowdcube, a prominent U.K. equity crowdfunding platform, Vismara (2016a) shows that crowd investors are attracted by campaigns whose early backers make their profile public on the platform, generating information cascades. Shafi (2019) finds that crowd investors place larger weight on factors that appear easy to evaluate and less weight on factors that are more difficult to evaluate. Thus, because of their cognitive limitations, crowd investors may exhibit more uncertainty in fully incorporating in their investment decisions the signal associated with ventures' VC-backing amid all the other information presented to them about an investment opportunity. In other words, they may miss this signal due to both attention limitation and their novice mental models about what constitutes quality in venture investing, and place more weight on other information such 
as endorsement by celebrities or the hype of an emerging industry in which the venture operates, that may materially be irrelevant if judged by VCs.

Conversely, we posit that crowd investors duly consider information on platforms' skin in the game in their investment decisions. Platform's skin in the game is an easily observable signal that reinforces the quality signal originally sent to crowd investors by VC-backed ventures. Crowd investors can reason that platforms are reluctant to retain ventures' equity as compensation unless these ventures have bright prospects. Crowd investors are also aware that platforms' skin in the game alleviates moral hazard problems, as it aligns platforms' incentives with their own incentives. Note that information from platform's skin in the game is more recent than that on ventures' receipt of equity funding from $\mathrm{VCs}$, leading crowd investors to place greater importance on it. This is consistent with the recency effect (recency bias), which describes the tendency for individuals to place disproportionate weight on more recent events and discount older information. The recency effect is specially pronounced as task complexity increases (Hogarth and Einhorn, 1992), which depends on both the amount of information that needs to be processed (information load) and lack of task familiarity, two conditions that clearly apply to crowd investors. This is so since individuals facing task complexity are likely to resort to strategies that overweight recent information to ease their cognitive strain (Payne, Payne, Bettman, and Johnson, 1993).

Based on the above arguments, we hypothesize that the quality signal generated by platforms having skin in the game mediates the relationship between ventures' VC-backing and the success of the crowdfunding campaigns, as reflected in the amount of capital raised by ventures and the number of backers of their campaigns.

Hypothesis 2a. The positive relationship between a focal venture's previous fundraising from professional investors and the amount raised in its equity crowdfunding campaign is mediated by the platform having skin in the game.

Hypothesis $\mathbf{2 b}$. The positive relationship between a focal venture's previous fundraising from professional investors and the number of backers of its equity crowdfunding campaign is mediated by the platform having skin in the game. 


\section{Methods}

\subsection{Data}

Several data sources are used in this study. We obtain information on all filings submitted to the SEC by ventures via EDGAR (SEC Electronic Data Gathering Analysis and Retrieval System). The crowdfunding offerings data set is available at https://www.sec.gov/dera/data/crowdf unding-offerings-data-sets. It includes information on the ventures (e.g., location, incorporation date, financial information, the number of employees, the name of officers), the campaign characteristics (e.g., offering amount, share price, type of security such as common stock, preferred stock, convertible notes, crowd notes, debt), the name of the intermediary platform, and other disclosures including the amount and form of compensation of the intermediary. Some filings also contain reports on progress update, which sometimes indicate the overall funding amount raised. ${ }^{5}$ We complement the information on amount of funding raised and the number of backers of the crowdfunding campaigns by manually looking up data from the platforms or other websites aggregating such data (e.g. crowditz.com, crowdlustro.com, zirra.com). We use LinkedIn to find information on ventures' CEOs. To find information on external funding from professional investors, we use Crunchbase, a database of investments and funding information about private and public ventures that is increasingly used by scholars (Cohen, Bingham, and Hallen, 2019).

Our sample includes information on 550 equity crowdfunding campaigns from May 2016 (first campaign filing date) to June 2018 (the last campaign filing date in our sample). From all securities filings submitted to the SEC, we only select those that are common stock or preferred stock (we exclude debt, convertible notes, token offerings, simple agreements for future equity, and tokens).

\footnotetext{
${ }^{5}$ Form $\mathrm{C}$ is the offering statement that all crowdfunding issuers must file with the SEC before initiating a crowdfunding campaign under Regulation Crowdfunding. A Form C filing should be followed by one of two types of SEC filings at the end of a securities crowdfunding campaign. Within five business days of the end of an offering, a company must report the total amount of securities sold on a progress update filing Form C-U, regardless of whether its campaign successfully raises funds. Alternatively, if the company withdraws its offering, it must file a withdrawal statement on Form C-W. There are also other filing obligations under Regulation Crowdfunding. An issuer that successfully raises funds is required to provide an annual report on Form C-AR after the end of its fiscal year unless certain criteria are met. Any issuer terminating its annual reporting obligations is required to file notice on Form C-TR.
} 


\subsection{Variables}

This study has two dependent variables: (1) Raised amount is the amount of money raised in U.S. dollars at the time the crowdfunding campaign ends; (2) No. of backers is the number of backers at the time the campaign ends. Both these variables are log-transformed after increasing by 1 to reduce skewness.

Prior VC funding, the main independent variable, is a dummy variable indicating whether ventures have already raised a round of funding from angel investors or venture capitalists before the beginning of the crowdfunding campaign.

Equity compensation, the mediating variable, is defined as the equity component of the compensation fee requested by the intermediaries. This variable is calculated by dividing the dollar pre-money value of the equity component of the compensation at the time of fundraising over the total dollar value of the compensation fee.

Our specifications include the following control variables, which are associated with fundraising success in prior research (Ahlers et al., 2015). Compensation is the ratio of the overall dollar value at the time of fundraising of the intermediary's compensation over the dollar value of the target goal. We adjust this variable to the target goal since compensations are mostly commensurate with the target goal. Like prior studies in crowdfunding (Shafi, 2019), we control for the Target goal that measures the funding goal in dollars that the campaign aims to raise. This variable is log-transformed. To control for the size of the venture, we include No. of employees and Revenue in million dollars (log transformed) both measured at the year of fundraising. To control for the existence of technological assets, we include the dummy variable Patent that equals one when a venture has applied for or has been granted a patent before starting the crowdfunding campaign; otherwise it is set to zero. To control for the certification effect from CEOs' educational achievements, we include the dummy variable CEO top university that equals one if the CEO has obtained degrees at any level of higher education from the top 20 national universities in the U.S. To create the list of the top 20 national universities, we use the 2019 US news national universities ranking. Finally, we control for legal status of incorporation for the venture. The legal forms include corporations, limited liability companies, limited partnerships, and general partnerships (the omitted category is Other as listed on SEC filings). 


\subsection{Specifications}

To test the mediation hypotheses, we estimate three separate OLS specifications (with robust standard errors) (Baron and Kenny, 1986; Aguinis, Edwards, and Bradley, 2017). In the first step of the mediation analysis, the outcome $Y_{i}$ of the focal venture's crowdfunding campaign, as reflected in the amount of fundraising (Raised amount ${ }_{i}$ ) and the number of backers $\left(\right.$ No. of backer $\left._{i}\right)$ respectively, is regressed on Prior $V C$ funding $_{i}$ and the control variables $C_{i}$, which relate to the characteristics of venture $i$ and it campaign (Equation 1).

$$
Y_{i}=\alpha+\beta_{1} \text { Prior VC funding } i+\Lambda C_{i}+\varepsilon_{i}
$$

In the second step of the mediation analysis, we regress Equity compensation E $_{i}$ the mediating variable $M_{i}$, on Prior $V C$ funding $_{i}$ and the controls $C_{i}$ (Equation 2). In the final step of the mediation analysis, the outcome $Y_{i}$ of the crowdfunding campaign is regressed on Prior $V C$ funding $_{i}$, the mediating variable $M_{i}$, and the control variables $C_{i}$ (Equation 3).

$$
\begin{gathered}
M_{i}=\alpha+\theta \text { Prior VC } \text { funding }_{i}+\gamma C_{i}+\varepsilon_{i} \\
Y_{i}=\alpha+\beta_{2} \text { Prior VC funding } i+\sigma M_{i}+\mu C_{i}+\varepsilon_{i}
\end{gathered}
$$

To establish positive mediation, three conditions should be met. First, Prior VC funding $_{i}$ influences both the crowdfunding campaign outcome $Y_{i}$ (the direct effect) in Equation 1 and the mediating variable $M_{i}$ in Equation $2\left(\beta_{1}>0\right.$ and $\left.\theta>0\right)$. Second, the mediating variable $M_{i}$, when inserted in the model specification in Equation 3, has a positive effect on the crowdfunding campaign outcome $Y_{i}(\sigma>0)$. Third, in Equation 3, the effect of Prior $V C$ funding $_{i}$ on the crowdfunding campaign outcome $Y_{i}$ is smaller than the one obtained by excluding the mediator in Equation 1 (i.e., partial mediation implies $\beta_{1}>\beta_{2}>0$ and full mediation implies null $\beta_{2}$ ).

The size and confidence intervals of the indirect effects and that of total effects are calculated by using the command paramed in Stata software. paramed performs (causal) mediation analysis using parametric regression models. We also obtain bias-corrected bootstrap confidence intervals with the use of bootstrap option and obtain similar results (available upon request). For the latest comparison of the mediation programs, see the work of Valente, Rijnhart, Smyth, Muniz, and MacKinnon (2020) that also reviews the underlying identification assumptions behind 
mediation models and application of paramed.

\section{$5 \quad$ Results}

Table 1 presents the descriptive statistics and the correlation matrix. Consistent with our expectations, there is a positive correlation between Prior VC funding and the dependent variables. Additionally, Prior VC funding is positively correlated with Equity compensation.

The estimates from testing Hypotheses 1 and 2a are presented in Table 2. Following Hypothesis 1, Model (1) predicts Equity Compensation based on Equation 2. Prior VC funding has a positive and statistically significant coefficient ( $\mathrm{p}$-value $=0.00$ ). The estimated difference in Equity compensation between ventures with and without prior $\mathrm{VC}$ funding is 4.5 percentage points. Given that the mean value of Equity compensation is 7 percent, this increase is quite notable. Thus, we find support for Hypothesis $1 .^{6}$

Models (2)-(4) in Table 2 estimate Equations 1 and 3, predicting Raised amount. Model (2) includes only the control variables. We first add Prior VC funding in Model (3) and then Equity compensation in Model (4). While the coefficient of Prior VC funding is positive and statistically significant in both Models (3) $(\mathrm{p}$-value $=0.00)$ and $(4)(\mathrm{p}$-value $=0.02)$, its magnitude decreases in Model (4), which includes the mediation variable Equity compensation, compared with Model (3), as was expected following Hypothesis 2a. In terms of economic magnitude, based on Model (3) the estimated amount raised by VC-backed ventures is 420 percent greater than the one of non-VC-backed ventures (i.e., 100( $\left.e^{1.649}-1=420\right)$. Based on Model (4), the average increase of Raised amount directly attributable to $\mathrm{VC}$ backing is about 20 percent (82 percentage points) lower than the one estimated from using Model (3) (i.e., 100( $\left.e^{1.478}-1\right)=338$ ). Additionally, an increase of one standard deviation in Equity compensation is associated with an estimated 70 percent increase in the amount of raised funding (i.e., $\left.100\left(e^{3.82 \times 0.138}-1\right)\right)$. The indirect effect of Prior VC funding on Raised amount that is mediated by Equity Compensation is approximately equal to 10 percent of the total effect.

To test Hypothesis 2b, we switch the dependent variable to No. of backers. The estimates are

\footnotetext{
${ }^{6}$ By comparison, a standard deviation increase of Compensation leads to a 4.9 percentage point increase in Equity compensation, while a standard deviation increase in Target goal generates a 3.3 percentage point increase in Equity compensation. The remaining variables are not statistically significant at conventional confidence levels.
} 
presented in Table 3. The sample size is smaller because of missing values on some campaigns. We re-estimate Equation 2 and obtain similar results on this sample. Prior VC funding has a positive effect on No. of backers that is still only weakly significant (p-value $=0.08$, see Model 3). Based on Model (3) the estimated number of backers by VC-backed ventures is 83 percent greater than the number of backers for non-VC-backed ventures (i.e., $\left.100\left(e^{0.607}-1\right)\right)$. When we add Equity compensation to the specification in Model (4), this variable coefficient is positive and weakly significant (p-value $=0.08)$. A one standard deviation increase in Equity compensation is associated with a 30 percent increase in the number of backers (i.e., $\left.100\left(e^{1.871 \times 0.138}-1\right)\right)$. In Model (4), the coefficient of Prior VC funding is positive but statistically less significant ( $\mathrm{p}$-value $=0.13)$. These results support Hypothesis $2 \mathrm{~b}$, indicating a (full) mediation effect for Equity compensation on the relationship between Prior VC funding and No. of backers.

\subsection{Endogeneity Concerns about Prior VC funding}

Potential endogeneity bias may arise since unobservable factors (e.g., the venture quality) may influence both the decisions of VC investors first and crowd investors later to fund a focal venture (beyond the observable path through the platform's skin in the game that is discussed in this paper). This unobserved heterogeneity can bias the estimated effect of Prior VC funding on the outcomes of the crowdfunding campaigns; ordinary least squares (OLS) estimates will likely be biased since they will capture both the average treatment effect of Prior VC funding and the bias caused by not controlling for the unobserved venture quality.

To correct for this potential endogeneity bias, we use the endogenous binary-variable model that Heckman (1979) introduced in econometric literature. Cameron and Trivedi (2005) (sec. 16.7 and 25.3.4) and Wooldridge (2010) discuss the endogenous binary-variable model as an endogenous treatment-effect model. This model is a special form of the Heckman selection model in which the outcome of the entire sample is observed as opposed to the outcomes of the treatment, as in the case of a selection model. ${ }^{7}$ We use a two-step approach (for binary treatment choices) that estimates a choice model in the first stage - noting that certain variables are included that meet relevance and exclusion restrictions. Following this first-stage estimation,

\footnotetext{
${ }^{7}$ Treatment effect models are distinct from sample selection models (for a discussion on this, see Li and Prabhala (2007)). Treatment effect models include the endogenous dummy variable as an independent regressor. Furthermore, for any given venture, we observe the outcome of a choice but not the outcomes of unmade choices. This missing information may result in a selection bias due to observables or unobservables.
} 
a bias correction term is calculated and included in the second stage to estimate the effect of the treatment on the outcome. This method is a standard approach to correct for the endogeneity of a binary treatment due to unobservable heterogeneity (Vella and Verbeek, 1999). We implement this method using etregress in Stata software.

We identify Top 3 VC funded regions as an instrumental variable that likely satisfies both relevance and exclusion restrictions in the two-step approach of endogenous treatment-effect model. Top $3 V C$ funded regions is a dummy variable that is equal to one if the venture is located in the top 3 regions in terms of venture capital investment based on the 2019 NVCA (National Venture Capital Association) report. These regions are: (1) Bay Area in California, (2) New York City, Northern New Jersey, and Long Island; and (3) Boston, Cambridge, and Quincy in Massachusetts and New Hampshire. The idea behind the relevance of this instrument proffers that when ventures are located in regions with abundant venture capital supply, they are more likely to receive funding, holding everything else constant. We are not suggesting that VC supply completely drives funding towards ventures, especially for all ventures. However, for some marginal ventures, increases in $\mathrm{VC}$ supply may make $\mathrm{VC}$ funding more accessible. From an econometric perspective, instruments are only good for marginal ventures: the best (and the worst) quality ventures are highly unlikely to be responsive to the changes in the VC supply in a region. That means instruments identify the local average treatment effect of the endogenous variable on the compliant subpopulation (Angrist and Pischke, 2009; Imbens and Wooldridge, 2009). In our context, our estimates thus likely identify how Prior VC funding affects crowdfunding outcomes for the subpopulation of ventures whose receipt of $\mathrm{VC}$ funding is affected by the changes in VC supply. These are likely to be marginal ventures, for which having a large infusion of $\mathrm{VC}$ in a given region can be the difference between obtaining $\mathrm{VC}$ funding or not. Accordingly, the instrument Top 3 VC funded regions identifies crowdfunding outcomes for middling ventures with prior $\mathrm{VC}$ funding. We also consider CEO top university and Venture age that provide additional control variables in the first stage regression. While our estimates predicting Prior VC funding based on these instruments presented in Table 4 suggest positive correlations, the assumption of exclusion restrictions are not empirically verifiable - effects of the proposed instruments on the outcome may not exclusively happen through its potential effect on Prior VC funding. An example of such violation would be if a majority of crowdinvestors (i.e., supply of equity crowdfunding) happen to come from the same regions with high amounts 
of $\mathrm{VC}$ funding and there is a strong local bias among equity crowdfunding investors. While we don't know locations of investors in our data-set to assess these conditions, scholars have debated these issues with some evidence for democratization premise in crowdfunding (Mollick and Robb, 2016) since funding platforms are Internet-based and broadcast information about opportunities to all investors regardless of their geographic distance. For example, Cumming, Meoli, and Vismara (2019a) find evidence that equity crowdfunding reduces some distance-related frictions between entrepreneurs and investors in the U.K. Overall, we acknowledge limitations inherent in our approach to addressing endogeneity concerns and have readers exercise caution before interpreting our results given the caveats around exclusion restrictions.

The maximum likelihood estimates are presented in Table 4. For the sake of brevity, we only present the results of the estimates of the first stage equation and the full specification of the second stage equation. The top (bottom) panel represents the second (first) stage estimates. In the first stage equation, the coefficient of Top $3 \mathrm{VC}$ funded regions is positive and statistically significant (p-value $=0.00$ in Model (1) relating to Raised amount and p-value $=0.00$ in Model (2) relating to No. of backers). The likelihood-ratio tests indicate that we can reject the null hypothesis of no correlation between the treatment-assignment errors and the outcome errors, i.e., the error terms in the first and second stages for Model $1\left(\chi^{2}(1)=3.81\right.$; p-value $\left.=0.05\right)$; but we don't do so for Model $(2)\left(\chi^{2}(1)=0.87 ; \mathrm{p}\right.$-value $\left.=0.35\right)$. The estimated correlation between the treatment-assignment errors and the outcome errors is -0.461 for Model (1) and -0.22 for Model (2). The negative correlation suggests that unobservable factors that are positively associated with the likelihood of receiving funding from professional investors before the crowdfunding campaigns tend to be negatively associated with the outcomes of the campaigns. ${ }^{8}$

The estimates of the second stage equations of Models (1) and (2) are similar to those presented earlier. Thus, the results of the estimates reconfirm that our theoretical hypotheses in the previous section are likely not driven by endogeneity of $\mathrm{VC}$ backing.

\footnotetext{
${ }^{8}$ For example, if professional investors select high-risk ventures aiming for highly skewed returns (say, funding moonshot projects in a portfolio approach), crowd investors might shun away these ventures and seek to invest in ventures whose prospects are more certain (say, crowds minimize the risk of losing all their investment).
} 


\section{Discussion and Final Remarks}

In this paper we have considered the role of intermediaries in alleviating adverse selection and moral-hazard problems in a market fraught with information asymmetries. Our sequential-stage signaling model suggests that intermediaries' skin in the game can effectively mediate signals from the issuer. We apply the sequential-stage signaling model to the context of equity crowdfunding, where crowdfunding platforms are intermediaries between ventures that are launching equity crowdfunding campaigns and crowd investors who are potentially interested in funding these campaigns. Based on data on 550 equity crowdfunding campaigns launched on U.S. crowdfunding platforms between May 2016 and June 2018, our findings indicate that while crowd investors pledge more to ventures that obtained prior equity funding from professional investors such as venture capitalists and business angels, this effect is partially mediated by the equity component of platforms' compensation for their intermediation services. When considering the number of crowd investors that back ventures' campaigns, the positive effect of the prior receipt of equity from professional investors appears to be fully mediated by platforms' skin in the game.

Our study offers several contributions to the literature. First, we contribute to signaling theory, specifically as it is applied in the strategic entrepreneurship field to answer the question of why some ventures have more success than others in raising capital (Block et al., 2018). Signaling theory posits that by using observable and costly-to-imitate attributes (qualified as signals), such as backing by professional investors, high quality ventures can credibly distinguish themselves from less promising counterparts. In this way, they increase the odds of acquiring additional external finance from prospective investors that face information asymmetry. However, this holds true under the assumption that prospective investors have the ability to correctly interpret the signals ventures are sending. Recent scholars including Drover et al. (2018) have started scrutinizing this assumption, pointing to the cognitive limitations of (some) prospective investors. Attention to this issue is certainly pertinent to small retail investors, such as crowd investors. We extend the application of signaling theory to a context that includes an intermediary facilitating the transactions between ventures and boundedly-rational prospective investors. The role of intermediaries can be ambiguous. Consider the case of equity crowdfunding platforms. One the one hand, platforms may have conflicts of interests with crowd investors, which can increase agency costs and exacerbate moral hazard problems. For instance, if the platforms' business 
model generates commission fees from brokering, platforms have an incentive to generate volume by listing a larger number of ventures, regardless of the long-term performance of the listed ventures. On the other hand, platforms are in a better position than crowd investors to screen and perform due diligence before listing the ventures and monitor them after the campaign. To resolve this tension, our theoretical developments highlight that the incentives of crowd investors and those of platforms are realigned if platforms retain an equity stake in the listed ventures as part of their compensation. Moreover, platforms are more inclined to ask for an equity stake in ventures that credibly signal their high quality, e.g. by being VC-backed. In turn, platforms' skin in the game is an additional signal of ventures' unobserved quality that crowd investors can easily observe and correctly interpret. The signal sent by platforms thus reinforces the signals originally sent by ventures in constructing the perceptions of crowd investors who may have cognitive limitations in assessing the quality of ventures. Overall, the positive effect of ventures' signals on crowd investors' investment decisions is mediated by platforms' skin in the game.

We also add to the literature interested in investigating the drivers of success of crowdfunding (Block et al., 2018; Colombo et al., 2015) and especially the role of governance in equity crowdfunding (see Cumming et al. (2019b) for a recent review). Most findings in the crowdfunding literature are based on a single platform as aptly noted by Dushnitsky and Zunino (2019). ${ }^{9}$ However, platforms differ in many dimensions across different countries including the extent of due diligence (Younkin and Kashkooli, 2016), shareholder structure, the voting rights for shareholders (Cumming, Meoli, and Vismara, 2018), legal restrictions on the permissible use of funds (Hornuf and Schwienbacher, 2018), and the existence of secondary markets. Our paper extends this list of governance differences by observing that platforms can take equity stake instead of fixed compensation fees for their services. This compensation form curbs adverse selection and moral hazard problems for crowd investors, thus contributing to the success of ventures' crowdfunding campaigns. This evidence complements the work by Cumming and Zhang (2018), who find that more extensive due diligence (as proxied by fewer campaigns per platform's employee, which increases platform employees' ability to carry out due diligence) by Canadian platforms is associated with a higher percentage of successful campaigns and a larger amount of capital raised on these platforms.

\footnotetext{
${ }^{9}$ There are some exceptions. For example, Hornuf and Schwienbacher (2018) find that market mechanisms of online platforms in Germany affect the campaign process and investors' decision-making.
} 
This study has certain limitations that offer opportunities for additional research. First, our results are based on equity crowdfunding campaigns launched on U.S. platforms. Regulations of equity crowdfunding vary across countries on a number of dimensions including maximum amounts allowed to be raised, securities to be issued, as well as types of companies that can use exemptions (see Vismara (2016a) and Hornuf and Schwienbacher (2018) for comparisons of securities crowdfunding regulations). While the securities crowdfunding market is premature and evolving in the U.S., the filing requirements under the SEC's Regulation Crowdfunding are more stringent than those of any other country (Australia and some European countries, notably the U.K., were the early movers, with their securities crowdfunding markets launched in the early 2010s). Given that findings from one country may not be easily generalizable to other countries with different regulations, future research can investigate the extent to which the regulatory regimes and the enforcement of those regulations influence the role of platforms, specially their ability to signal to crowd investors the unobserved quality of listed ventures.

The second limitation of this study relates to lack of data on individuals investing in equity crowdfunding campaigns. Our theory assumes that crowd investors have cognitive limitations, and thus does not apply to professional investors who have access to financial resources, experience, and expertise to perform extensive due diligence. The observations that professional investors, specially business angels, are sometimes active in equity crowdfunding and generally commit to listed ventures a larger amount of funds (to make it worth their effort) may explain the divergence of our results relating to the amount of funding raised by ventures and the number of their backers. We show that platforms' skin in the game fully mediates the positive effect of ventures' prior $\mathrm{VC}$ backing on the number of backers of the crowdfunding campaigns, but only partially mediates the effect on the amount of funding raised by ventures. We believe that the amount of funding raised on crowdfunding platforms may be sensitive to the funds committed by a few professional investors. These investors can easily interpret the quality signals sent by ventures, without relying on platforms' skin of the game to decide about their investments. This would reduce the observed mediation effect of platforms' skin in the game. If data on individual investors were available, one could separately investigate the investment decisions of crowd and professional investors, and gain additional insights on the different intermediation role played by platforms for these two categories of investors.

A final limitation of this study relates to our focus on a single important signal: the receipt 
of external funding from business angels and venture capitalists. Previous studies highlight that ventures use different signals to attract crowd investors (Ahlers et al., 2015; Piva and RossiLamastra, 2018). These signals can be sometimes complex to interpret for crowd investors (Shafi, 2019). Moreover, they likely reinforce each other if they are congruent, or generate greater uncertainty if they are not, which can ultimately deter crowd investors. It would then be interesting to assess how platforms' actions, and notably their skin in the game, mediate the effects of these multiple signals, taken in isolation or in combination, on the outcomes of the crowdfunding campaigns.

In spite of these limitations, our work has important implications for entrepreneurs, crowd investors, platforms, and policy makers. The medium of information exchange for crowdfunding is predominantly the Internet and this might limit the richness of interactions between entrepreneurs and crowd investors. This problem is often exacerbated by two related observations: (1) ventures have an incentive to present only what is favorable for their funding on these platforms; and (2) platforms seek to frame in a standardized way all the information on ventures' business model and future prospects. While platforms try to ensure transparent communication between entrepreneurs and potential investors (e.g., using forums and live-video conferences), it remains unclear whether crowd investors have the incentives and abilities to correctly process this information. Our findings suggest that actions taken by platforms indicating the high quality of the listed ventures (like having skin in the game) are probably more informative for crowd investors. As to platforms, our findings show the positive effects of retaining skin in the game on the success of the crowdfunding campaigns. However, it is important for platforms to realize that skin in the game can turn into a double-edged sword. In particular, platforms must devise suitable strategies to limit the negative implications on listed ventures' ability to attract crowd investors that may arise from not requesting equity as part of their compensation (see Shafi et al. (2019) for similar arguments that show negative signals associated with withdrawing follow-on funding from existing VCs). Lastly, in regulating crowdfunding platforms, policy makers should take heed that these funding portals are not passive, and their characteristics and actions affect ventures' funding outcomes, as we show in this study in relation to platforms' financial interests in listed ventures. Thus, policy makers interested in harnessing the potential of crowdfunding markets for addressing the funding gaps of early stage ventures should consider assuring full transparency in disclosing platforms' actions, as this information can help 
overcome the cognitive limitations of crowd investors and facilitate welfare-improving financial transactions.

\section{References}

Agarwal, S., Amromin, G., Ben-David, I., Chomsisengphet, S., Evanoff, D. D., 2010. Learning to cope: Voluntary financial education and loan performance during a housing crisis. American Economic Review 100, 495-500.

Aguinis, H., Edwards, J. R., Bradley, K. J., 2017. Improving our understanding of moderation and mediation in strategic management research. Organizational Research Methods 20, 665685 .

Ahlers, G. K., Cumming, D., Günther, C., Schweizer, D., 2015. Signaling in equity crowdfunding. Entrepreneurship theory and practice 39, 955-980.

Angrist, J. D., Pischke, J.-S., 2009. Instrumental variables in action: sometimes you get what you need. Mostly Harmless Econometrics: An Empiricist's Companion pp. 113-218.

Baron, R. M., Kenny, D. A., 1986. The moderator-mediator variable distinction in social psychological research: Conceptual, strategic, and statistical considerations. Journal of personality and social psychology 51, 1173.

Bergh, D. D., Connelly, B. L., Ketchen Jr, D. J., Shannon, L. M., 2014. Signalling theory and equilibrium in strategic management research: An assessment and a research agenda. Journal of Management Studies 51, 1334-1360.

Bertoni, F., Colombo, M. G., Grilli, L., 2011. Venture capital financing and the growth of hightech start-ups: Disentangling treatment from selection effects. Research Policy 40, 1028-1043.

Block, J. H., Colombo, M. G., Cumming, D. J., Vismara, S., 2018. New players in entrepreneurial finance and why they are there. Small Business Economics 50, 239-250.

Brealey, R., Leland, H. E., Pyle, D. H., 1977. Informational asymmetries, financial structure, and financial intermediation. The journal of Finance 32, 371-387.

Busenitz, L. W., Barney, J. B., 1997. Differences between entrepreneurs and managers in large organizations: Biases and heuristics in strategic decision-making. Journal of business venturing $12,9-30$.

Cameron, A. C., Trivedi, P. K., 2005. Microeconometrics: methods and applications. Cambridge university press.

Chemla, G., Hennessy, C. A., 2014. Skin in the game and moral hazard. The Journal of Finance $69,1597-1641$.

Chemmanur, T. J., Krishnan, K., Nandy, D. K., 2011. How does venture capital financing improve efficiency in private firms? a look beneath the surface. The Review of Financial Studies 24, 4037-4090.

Cohen, S. L., Bingham, C. B., Hallen, B. L., 2019. The role of accelerator designs in mitigating bounded rationality in new ventures. Administrative Science Quarterly 64, 810-854. 
Colombo, M. G., Franzoni, C., Rossi-Lamastra, C., 2015. Internal social capital and the attraction of early contributions in crowdfunding. Entrepreneurship Theory and Practice 39, $75-100$.

Colombo, M. G., Grilli, L., 2010. On growth drivers of high-tech start-ups: Exploring the role of founders' human capital and venture capital. Journal of business venturing 25, 610-626.

Colombo, M. G., Meoli, M., Vismara, S., 2019. Signaling in science-based ipos: The combined effect of affiliation with prestigious universities, underwriters, and venture capitalists. Journal of Business Venturing 34, 141-177.

Colombo, M. G., Shafi, K., 2019. Receiving external equity following successfully crowdfunded technological projects: an informational mechanism. Small Business Economics pp. 1-23.

Connelly, B. L., Certo, S. T., Ireland, R. D., Reutzel, C. R., 2011. Signaling theory: A review and assessment. Journal of management 37, 39-67.

Cooper, A. C., Woo, C. Y., Dunkelberg, W. C., 1988. Entrepreneurs' perceived chances for success. Journal of business venturing 3, 97-108.

Cumming, D., Meoli, M., Vismara, S., 2018. Does equity crowdfunding democratize entrepreneurial finance? Small Business Economics pp. 1-20.

Cumming, D., Meoli, M., Vismara, S., 2019a. Does equity crowdfunding democratize entrepreneurial finance? Small Business Economics pp. 1-20.

Cumming, D. J., Vanacker, T., Zahra, S. A., 2019b. Equity crowdfunding and governance: Toward an integrative model and research agenda. Academy of Management Perspectives .

Cumming, D. J., Zhang, Y., 2018. Are crowdfunding platforms active and effective intermediaries? Available at SSRN 2882026 .

DeMarzo, P., Duffie, D., 1999. A liquidity-based model of security design. Econometrica 67, 65-99.

DeMarzo, P. M., 2005. The pooling and tranching of securities: A model of informed intermediation. The Review of Financial Studies 18, 1-35.

Demiroglu, C., James, C., 2012. How important is having skin in the game? originator-sponsor affiliation and losses on mortgage-backed securities. The Review of Financial Studies 25, 32173258 .

Drover, W., Wood, M. S., Corbett, A. C., 2018. Toward a cognitive view of signalling theory: individual attention and signal set interpretation. Journal of Management Studies 55, 209-231.

Dushnitsky, G., Zunino, D., 2019. The role of crowdfunding in entrepreneurial finance. In: Handbook of research on crowdfunding, Edward Elgar Publishing.

Gorman, M., Sahlman, W. A., 1989. What do venture capitalists do? Journal of business venturing 4, 231-248.

Gorton, G. B., Pennacchi, G. G., et al., 1995. Banks and loan sales marketing nonmarketable assets. Journal of Monetary Economics 35, 389-411.

Hartman-Glaser, B., 2017. Reputation and signaling in asset sales. Journal of Financial Economics $125,245-265$.

Heckman, J. J., 1979. Sample selection as a specification error. Econometrica 47, 153-161. 
Hertzel, M., Smith, R. L., 1993. Market discounts and shareholder gains for placing equity privately. The Journal of finance 48, 459-485.

Hochberg, Y. V., Ljungqvist, A., Lu, Y., 2007. Whom you know matters: Venture capital networks and investment performance. The Journal of Finance 62, 251-301.

Hogarth, R. M., Einhorn, H. J., 1992. Order effects in belief updating: The belief-adjustment model. Cognitive psychology 24, 1-55.

Holmstrom, B., Tirole, J., 1997. Financial intermediation, loanable funds, and the real sector. the Quarterly Journal of economics 112, 663-691.

Hornuf, L., Schwienbacher, A., 2018. Market mechanisms and funding dynamics in equity crowdfunding. Journal of Corporate Finance 50, 556-574.

Huang, L., Pearce, J. L., 2015. Managing the unknowable: The effectiveness of early-stage investor gut feel in entrepreneurial investment decisions. Administrative Science Quarterly 60, 634-670.

Imbens, G. W., Wooldridge, J. M., 2009. Recent developments in the econometrics of program evaluation. Journal of economic literature 47, 5-86.

Kerr, W. R., Lerner, J., Schoar, A., 2014. The consequences of entrepreneurial finance: Evidence from angel financings. The Review of Financial Studies 27, 20-55.

Keys, B. J., Mukherjee, T., Seru, A., Vig, V., 2010. Did securitization lead to lax screening? evidence from subprime loans. The Quarterly journal of economics 125, 307-362.

Khoury, T. A., Junkunc, M., Deeds, D. L., 2013. The social construction of legitimacy through signaling social capital: Exploring the conditional value of alliances and underwriters at ipo. Entrepreneurship Theory and Practice 37, 569-601.

Kleinert, S., Volkmann, C., Grünhagen, M., 2018. Third-party signals in equity crowdfunding: the role of prior financing. Small Business Economics pp. 1-25.

Kleinert, S., Volkmann, C., Grünhagen, M., 2020. Third-party signals in equity crowdfunding: the role of prior financing. Small Business Economics 54, 341-365.

Li, K., Prabhala, N. R., 2007. Self-selection models in corporate finance. handbook of corporate finance: Empirical corporate finance.

Lukkarinen, A., Teich, J. E., Wallenius, H., Wallenius, J., 2016. Success drivers of online equity crowdfunding campaigns. Decision Support Systems 87, 26-38.

Mamonov, S., Malaga, R., 2019. Success factors in title ii equity crowdfunding in the united states. Venture Capital 21, 223-241.

Mian, A., Sufi, A., 2009. The consequences of mortgage credit expansion: Evidence from the us mortgage default crisis. The Quarterly Journal of Economics 124, 1449-1496.

Mollick, E., Robb, A., 2016. Democratizing innovation and capital access: The role of crowdfunding. California management review 58, 72-87.

Payne, J. W., Payne, J. W., Bettman, J. R., Johnson, E. J., 1993. The adaptive decision maker. Cambridge university press.

Pennacchi, G. G., 1988. Loan sales and the cost of bank capital. The Journal of Finance 43, 375-396. 
Piva, E., Rossi-Lamastra, C., 2018. Human capital signals and entrepreneurs' success in equity crowdfunding. Small Business Economics 51, 667-686.

Pollock, T. G., Chen, G., Jackson, E. M., Hambrick, D. C., 2010. How much prestige is enough? assessing the value of multiple types of high-status affiliates for young firms. Journal of Business Venturing 25, 6-23.

Puri, M., Zarutskie, R., 2012. On the life cycle dynamics of venture-capital-and non-venturecapital-financed firms. The Journal of Finance 67, 2247-2293.

Purnanandam, A., 2011. Originate-to-distribute model and the subprime mortgage crisis. The review of financial studies 24, 1881-1915.

Rajan, U., Seru, A., Vig, V., 2010. Statistical default models and incentives. American Economic Review 100, 506-10.

Ralcheva, A., Roosenboom, P., 2018. Forecasting success in equity crowdfunding. Small Business Economics pp. 1-18.

Ralcheva, A., Roosenboom, P., 2019. Forecasting success in equity crowdfunding. Small Business Economics pp. 1-18.

Shafi, K., 2019. Investors' evaluation criteria in equity crowdfunding. Small Business Economics

Shafi, K., Mohammadi, A., Johan, S. A., 2019. Investment ties gone awry. Academy of Management Journal .

Simon, H. A., 1947. Administrative behavior. Free Press, New York, fourth ed.

Spence, M., 1973. Job market signaling. The Quarterly Journal of Economics 87, 355-374.

Steigenberger, N., Wilhelm, H., 2018. Extending signaling theory to rhetorical signals: Evidence from crowdfunding. Organization Science 29, 529-546.

Stiglitz, J. E., 1985. Credit markets and the control of capital. Journal of Money, credit and Banking 17, 133-152.

Stuart, T. E., Hoang, H., Hybels, R. C., 1999. Interorganizational endorsements and the performance of entrepreneurial ventures. Administrative science quarterly 44, 315-349.

Valente, M. J., Rijnhart, J. J., Smyth, H. L., Muniz, F. B., MacKinnon, D. P., 2020. Causal mediation programs in $\mathrm{r}$, $\mathrm{m}$ plus, sas, spss, and stata. Structural Equation Modeling: A Multidisciplinary Journal pp. 1-10.

Vanacker, T., Forbes, D. P., 2016. Disentangling the multiple effects of affiliate reputation on resource attraction in new firms. Organization Science 27, 1525-1547.

Vanacker, T., Forbes, D. P., Knockaert, M., Manigart, S., 2020. Signal strength, media attention, and resource mobilization: evidence from new private equity firms. Academy of Management Journal 63, 1082-1105.

Vella, F., Verbeek, M., 1999. Two-step estimation of panel data models with censored endogenous variables and selection bias. Journal of Econometrics 90, 239-263.

Vismara, S., 2016a. Equity retention and social network theory in equity crowdfunding. Small Business Economics 46, 579-590. 
Vismara, S., 2016b. Information cascades among investors in equity crowdfunding. Entrepreneurship Theory and Practice .

Wooldridge, J. M., 2010. Econometric analysis of cross section and panel data. MIT press.

Younkin, P., Kashkooli, K., 2016. What problems does crowdfunding solve? California Management Review 58, 20-43.

Zhang, B., Ziegler, T., Mammadova, L., Johanson, D., Gray, M., Yerolemou, N., 2018. The 5th uk alternative finance industry report. Tech. rep., The Cambridge Centre for Alternative Finance. 


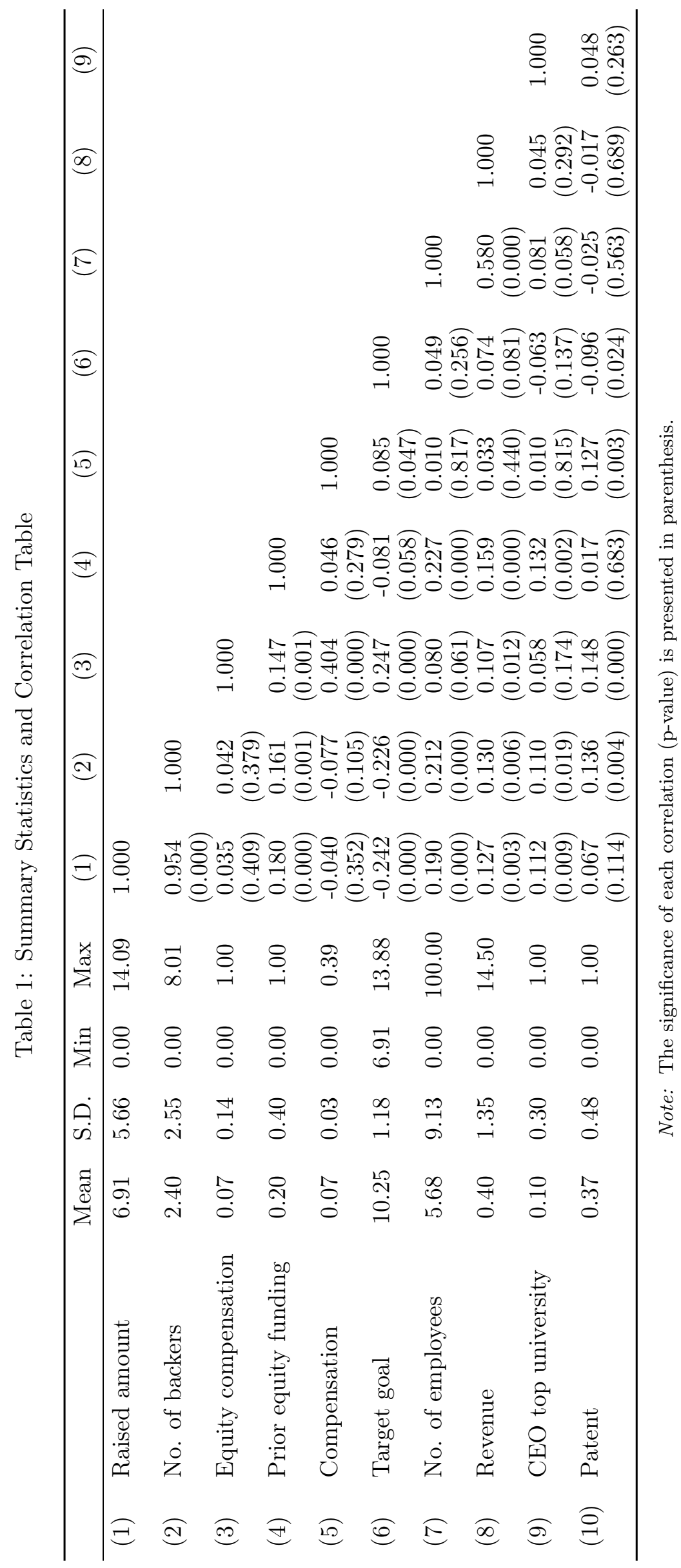




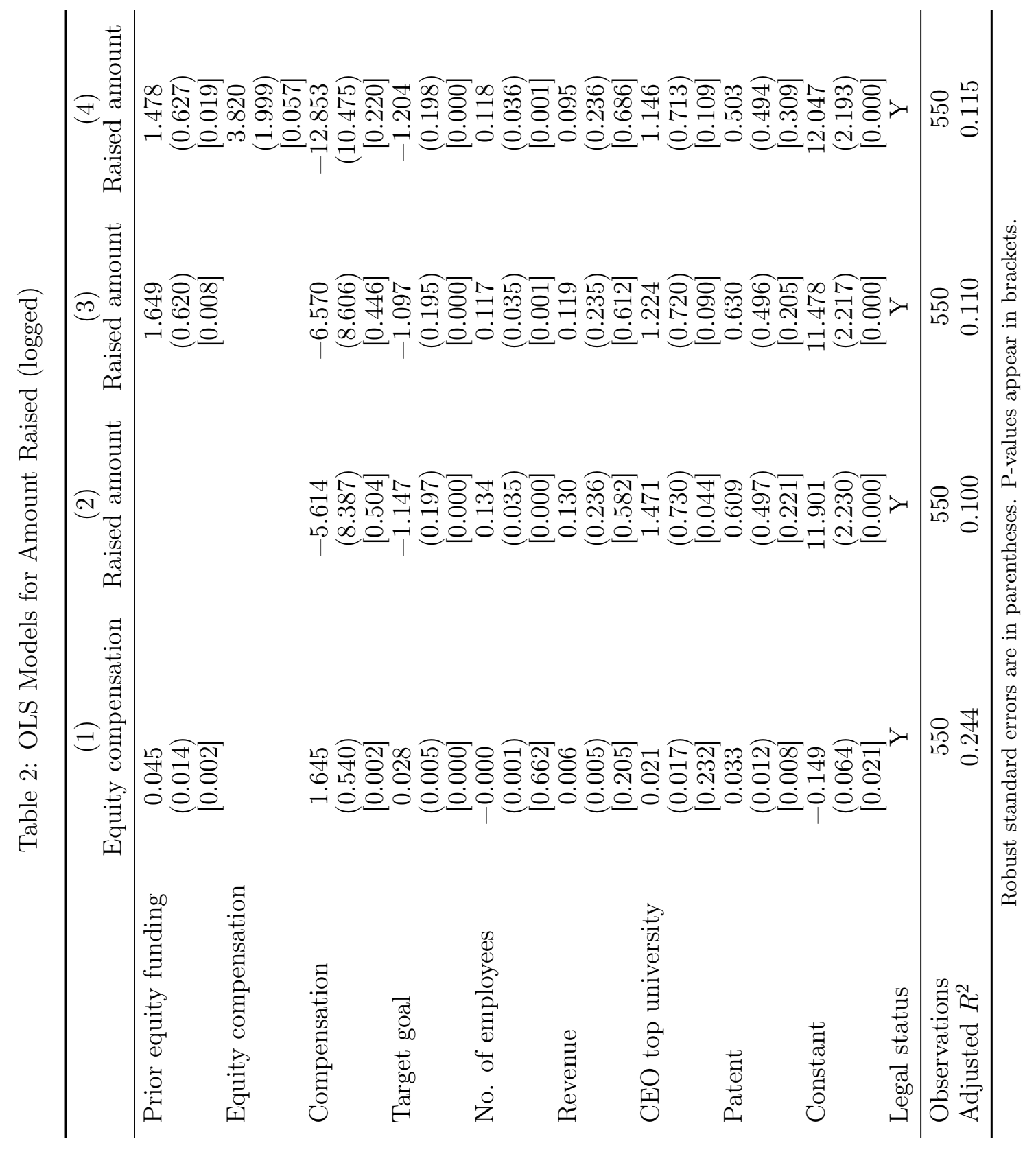




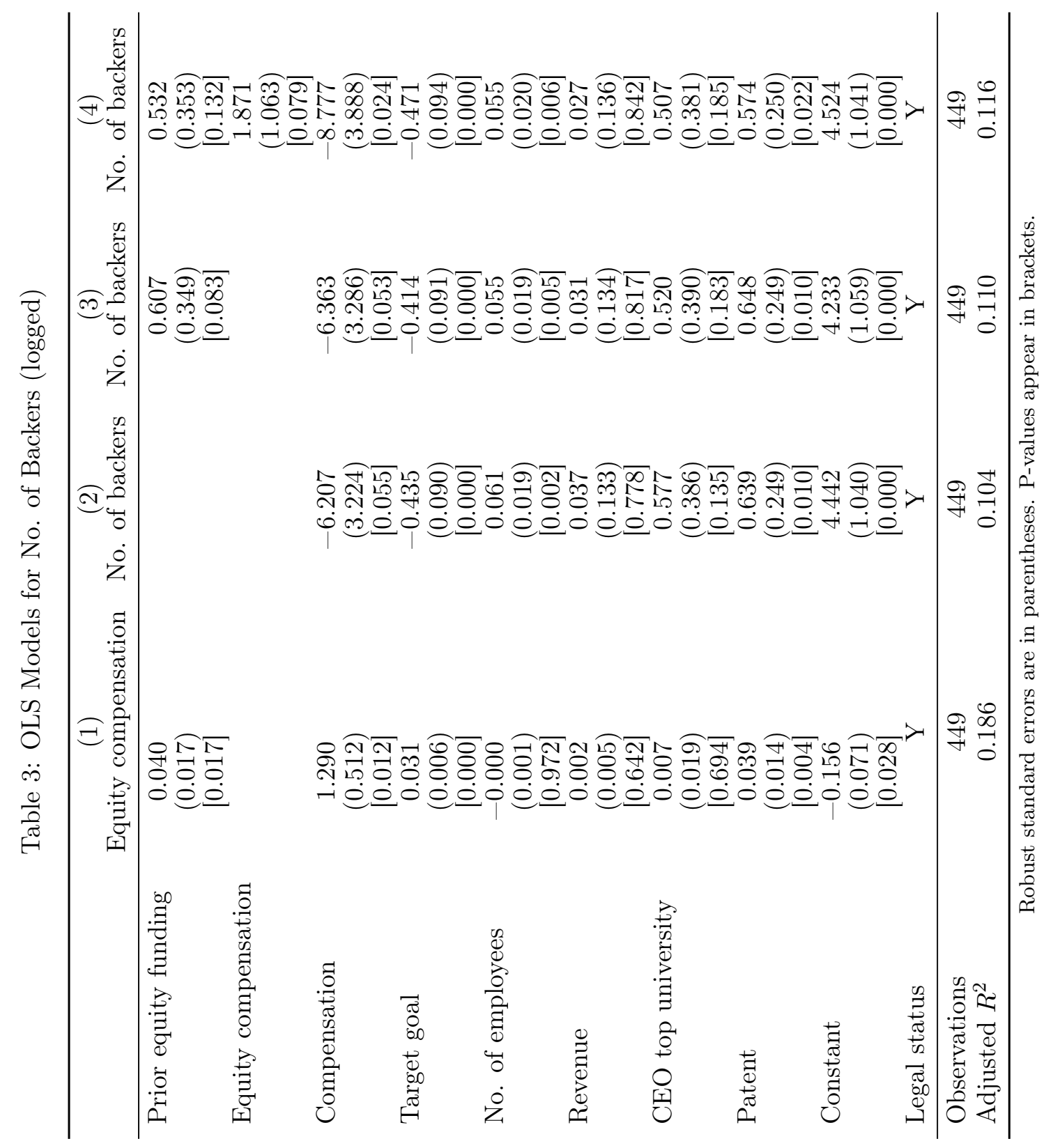


Table 4: Linear regressions with endogenous treatment effects

\begin{tabular}{|c|c|c|}
\hline & $\begin{array}{c}(1) \\
\text { Raised amount }\end{array}$ & $\begin{array}{c}(2) \\
\text { No. of backers }\end{array}$ \\
\hline Prior equity funding & $\begin{array}{l}5.444 \\
(2.039) \\
{[0.008]}\end{array}$ & $\begin{array}{c}1.443 \\
(1.011) \\
0.1541\end{array}$ \\
\hline Equity compensation & $\begin{array}{c}3.646 \\
(1.873) \\
{[0.052]}\end{array}$ & $\begin{array}{c}1.819 \\
(0.907) \\
{[0.045]}\end{array}$ \\
\hline Compensation & $\begin{array}{r}-12.926 \\
(8.216) \\
\mid 0.116\rceil\end{array}$ & $\begin{array}{r}-8.749 \\
(3.813) \\
{[0.022]}\end{array}$ \\
\hline Target goal & $\begin{array}{c}-1.208 \\
(0.201) \\
0.000\end{array}$ & $\begin{array}{c}-0.474 \\
(0.100) \\
{[0.000]}\end{array}$ \\
\hline No. of employees & $\begin{array}{c}0.117 \\
(0.036) \\
{[0.001]}\end{array}$ & $\begin{array}{c}0.055 \\
(0.019) \\
{[0.003]}\end{array}$ \\
\hline Revenue & $\begin{array}{c}0.025 \\
(0.210) \\
{[0.904]}\end{array}$ & $\begin{array}{c}0.009 \\
(0.107) \\
{[0.932]}\end{array}$ \\
\hline CEO top university & $\begin{array}{c}0.464 \\
(0.856) \\
{[0.588]}\end{array}$ & $\begin{array}{c}0.397 \\
(0.408) \\
{[0.331]}\end{array}$ \\
\hline Patent & $\begin{array}{c}0.499 \\
(0.478) \\
{[0.297]}\end{array}$ & $\begin{array}{c}0.567 \\
(0.238) \\
{[0.017]}\end{array}$ \\
\hline Constant & $\begin{array}{l}13.200 \\
(4.129) \\
0.001]\end{array}$ & $\begin{array}{c}6.218 \\
(1.983) \\
{[0.002]}\end{array}$ \\
\hline Legal status & $\mathrm{Y}$ & $\mathrm{Y}$ \\
\hline & $\begin{array}{l}\text { First stage } \\
\end{array}$ & $\begin{array}{l}\text { stage } \\
\text { Prior equity funding }\end{array}$ \\
\hline Top 3 VC funded regions & $\begin{array}{c}0.463 \\
(0.143) \\
{[0.001]}\end{array}$ & $\begin{array}{l}0.500 \\
(0.166) \\
0.003]\end{array}$ \\
\hline CEO top university & $\begin{array}{c}0.481 \\
(0.195) \\
{[0.014]}\end{array}$ & $\begin{array}{c}0.368 \\
(0.231) \\
{[0.111]}\end{array}$ \\
\hline Age & $\begin{array}{c}0.043 \\
(0.012) \\
{[0.001]}\end{array}$ & $\begin{array}{c}0.047 \\
(0.014) \\
{[0.001]}\end{array}$ \\
\hline Constant & $\begin{array}{c}-0.340 \\
(0.610) \\
{[0.577]}\end{array}$ & $\begin{array}{r}-0.799 \\
(0.739) \\
{[0.280]}\end{array}$ \\
\hline Legal status & $\mathrm{Y}$ & $\mathrm{Y}$ \\
\hline $\begin{array}{l}\text { Observations } \\
\text { Log pseudolikelihood }\end{array}$ & $\begin{array}{c}550 \\
-1941\end{array}$ & $\begin{array}{c}449 \\
-1213\end{array}$ \\
\hline
\end{tabular}

Robust standard errors are in parentheses. P-values appear in brackets. 